\title{
Vitamin D Receptor Alleles, Bone Mineral Density and Turnover in Postmenopausal Osteoporotic and Healthy Women
}

\author{
Belgin Süsleyici Duman ${ }^{a}$ Refik Tanakol ${ }^{b}$ Nevin Erensoyc Melek Öztürk $^{c}$ \\ Selma Yılmazerc \\ aDepartment of Medical Biology and Genetics, Kadir Has University Medical Faculty, Gayrettepe-Istanbul, and \\ Departments of ${ }^{b}$ Endocrinology and Metabolism and ${ }^{c}$ Medical Biology, Istanbul University Faculty of Medicine, \\ Çapa-Istanbul, Istanbul, Turkey
}

\section{Key Words}

Bone mineral density - Vitamin D receptor gene polymorphism · Osteoporosis · Menopause

\begin{abstract}
Objective: Vitamin D receptor (VDR) gene polymorphisms and bone metabolic markers were investigated as potential genetic markers for osteoporosis in postmenopausal Turkish women. The relationship between their VDR gene polymorphisms and bone states was determined. Materials and Methods: Restriction fragment length polymorphisms at the VDR gene locus (i.e., for Bsml, Apal, and Taql) was investigated in 75 postmenopausal osteoporotic (53.16 \pm 1.31 years) and 66 healthy (52.62 \pm 1.69 years) Turkish women and the genotypes were related to bone mineral density (BMD) at femoral neck (FN), lumbar spine (L1-4), trochanter, Ward's triangle (Ward's) and metabolic parameters of bone turnover. Results: In osteoporotic women, Taql genotype-related differences of the VDR gene were found to be significant at all BMD sites; TT genotype had higher L1-4 BMD values than Tt and tt $(p<0.05)$; tt genotype had significantly lower BMD at FN ( $p<0.05$ ), trochanter $(p<0.01)$, and Ward's $(p<0.05)$ compared to TT
\end{abstract}

genotype. The tt genotype was found to be associated with higher $(p<0.05)$ serum osteocalcin levels compared to Tt and TT genotypes in the osteoporotic women, whereas no such association was found for the healthy women. Conclusion: Our data showed an association between VDR Taql genotype and BMD at the FN, L1-4, trochanter and Ward's triangle in nonobese postmenopausal osteoporotic women. Thus the VDR gene Taql polymorphism modulates differences in BMD in the postmenopausal osteoporotic women.

Copyright @ 2004 S. Karger AG, Basel

\section{Introduction}

Osteoporosis is characterized by low bone mineral density (BMD) and microarchitectural deterioration of bone leading to increased bone fragility and a high risk of fracture. BMD is influenced by genetic factors [1] and several twin studies suggest that genetic factors account for as much as $80 \%$ of total variance of BMD, the major predictor of osteoporosis and fragility fractures [1-7].

Although studies performed by Morrison et al. [8, 9] have focused attention on the possibility that polymorphisms in the vitamin $\mathrm{D}$ receptor (VDR) gene may

\begin{tabular}{ll}
\hline KARGER & ( ) 2004 S. Karger AG, Basel \\
Fax +41613061234 & 1011-7571/04/0135-0260\$21.00/0 \\
$\begin{array}{l}\text { E-Mail karger@karger.ch } \\
\text { www.karger.com }\end{array}$ & $\begin{array}{l}\text { Accessible online at: } \\
\text { www.karger.com/mpp }\end{array}$
\end{tabular}

Selma Yilmazer

Department of Medical Biology, Cerrahpaşa Faculty of Medicine Istanbul University, TR-34310 Cerrahpaşa-Istanbul (Turkey)

Tel. +90 2125884800 , ext. 2032, Fax +90 2126320050

E-Mail selmayilmazer@mynet.com 
account for a significant part of this variation, the distribution of BMD in the population strongly suggests a polygenic inheritance [10,11]. Several groups have studied the relationship between VDR and bone mass as well as bone turnover in different populations, and obtained discordant results [8, 12-23]. In Australian women of EnglishIrish descent, after adjustment for age and environmental factors, subjects with BB or the tt genotype were found to have higher serum osteocalcin levels and lower BMD than those with the bb or TT genotypes. Heterozygotes $(\mathrm{Bb} / \mathrm{Tt})$ had intermediate values [8]. Furthermore, the BB genotype is associated with a higher rate of bone loss in premenopausal Japanese women [12] and in postmenopausal Caucasian women $[13,14]$. These findings show an active role of the VDR genotype in determining bone density in postmenopausal women. Other studies have found a correlation between the BMD and VDR genotype [15-17], while others still have failed to detect such a correlation [18-23]. In general, the studies that have detected lower BMD found smaller differences between groups than that reported by Morrison et al. [9]. The ethnic differences among the study populations may explain this variability to some extent but only a few studies have focused on this issue $[22,24,25]$.

No data have yet been published examining the prevalence and relevance of the various VDR polymorphisms in Turkish women. We therefore studied VDR genotypes in Turkish postmenopausal osteoporotic women and examined the relationship between the genotypes defined by the polymorphisms ApaI, BsmI, and TaqI at the L1-4, the femoral neck (FN), trochanter and Ward's triangle in healthy and osteoporotic women. The major aim of this study was to define the possible associations of VDR gene alleles and bone turnover markers with BMD.

\section{Materials and Methods}

\section{Subjects and Bone Density Measurements}

Seventy-five postmenopausal osteoporotic (53.16 \pm 1.31 years) and 66 healthy $(52.62 \pm 1.69$ years) women were included in the study. All osteoporotic women had a BMD of at least 2.5 SD below the mean value of healthy premenopausal women in either the hip or spine. The control group consisted of healthy, age- and risk factormatched subjects with BMD \pm 1 SD T score. A detailed medical history was obtained and physical examination was performed by one of the investigators (R.T.). Patients were excluded from the study on the basis of the following criteria: presence of concomitant disease (disorders of calcium metabolism, renal, thyroid, hepatic dysfunction, Paget's disease, Cushing's syndrome, sarcoidosis, rheumatoid arthritis, malignancy, malabsorption, and malnutrition), previous use of oral/transdermal hormone replacement therapy or any other osteoporosis treatment, thyroid hormone replacement, glucocorticoid or anticonvulsant drug, biochemical evidence of osteomalacia and severe osteoarthritis. Osteoporosis risk factors, such as cigarette smoking, premenstrual irregularity of menses, insufficient sun exposure and calcium intake as well as sodium, protein, coffee and alcohol consumption, and physical activity, were assessed by a questionnaire. Lateral radiographs of the spine were examined, and the compression fracture was defined as $>20 \%$ reduction in anterior height. $\mathrm{BMD}$ of the lumbar spine and proximal femur in grams per square centimeter was measured by dual energy X-ray absorptiometry (Hologic QDR 1000 Plus, USA).

\section{Measurement of Bone Turnover Markers}

Following an overnight fast, urine samples for the measurement of 24-hour calcium and hydroxyproline [26] were collected and measured. Serum calcium and osteocalcin were also measured. Body mass index was calculated as an estimate of obesity [weight $(\mathrm{kg}) /$ height $\left.\left(\mathrm{m}^{2}\right)\right]$.

\section{Genotype Assignment}

Genomic DNA was prepared from $10 \mathrm{ml}$ of EDTA-treated blood with a simple salting-out procedure [27]. The DNA sequences were amplified by polymerase chain reaction (PCR) [28]. Detection of the $B s m I$ site in intron 8 was performed by PCR amplification of a region carrying the $B s m \mathrm{I}$ site with primers originating in exon 7 (primer 1: 5'-CAA CCAAGACTACAAGTACCGCGTCAGTGA-3') and intron 8 (primer 2: 5'-AACCAGCGGGAAGAGGTCAAGGG$3^{\prime}$ ) producing an 825-basepair (bp) fragment [9]. To amplify the VDR DNA sequence carrying $A p a \mathrm{I}$ and $T a q \mathrm{I}$ sites, primers in intron 8 (5'-CAGAGCATGGACAGGGAGCAAG-3') and exon 9 (5'GCAACTCCTCATGGCTGAGGTCTCA- ${ }^{\prime}$ ) were used which produced a 740-bp fragment [8]. PCR products were generated in a $60-\mu 1$ reaction volume containing 100-200 ng of DNA, $0.5 \mu M$ of each primer, $200 \mu M$ of dNTPs, $50 \mathrm{~m} M \mathrm{KCl}, 10 \mathrm{~m} M$ Tris- $\mathrm{HCl}(\mathrm{pH}=9.0$ ), $1.5 \mathrm{mM} \mathrm{MgCl} 2,0.1 \%$ Triton X-100, and $0.8 \mathrm{U}$ of Taq DNA polymerase.

To determine the presence of a restriction site within an amplified product, a $10-\mu 1$ aliquot was digested with $5 \mathrm{U}$ of endonuclease Bsm I at $65^{\circ} \mathrm{C}, A p a \mathrm{I}$ at $37^{\circ} \mathrm{C}$, or $\operatorname{Taq} \mathrm{I}$ at $65^{\circ} \mathrm{C}$ for $1 \mathrm{~h}$. Digestion products were electrophoresed in a $2 \%$ agarose gel containing ethidium bromide $(50 \mu \mathrm{g} / \mathrm{ml})$. DNA fragments were visualized by ultraviolet illumination and fragment sizes estimated by comparison to the 50-bp ladder run on the same gel. The genotype detection protocol was repeated 2 times for the heterozygous samples to eliminate the probability of partial digestion. The presence of the BsmI restriction site generates 175- and 650-bp fragments, whereas the absence of this site yields a 825 -bp fragment. The homozygous absence of the TaqI site yields bands of 245 and $495 \mathrm{bp}$, whereas the homozygous presence of this site yields fragments of 205, 245 and $290 \mathrm{bp}$. Heterozygotes for the TaqI site exhibit fragments of 490, 290, 245 and 205 bp. Digestion of the 740-bp PCR product with ApaI gives fragments of 220 and $520 \mathrm{bp}$ for the presence of the restriction site, whereas the absence of the restriction site leaves the PCR product undigested. The presence of the restriction enzyme site is indicated by a lowercase letter and the absence of the site by an uppercase letter.

\section{Statistical Analysis}

Statistical analyses were conducted using Unistat 5.1 software. Rare genotypes ( $\mathrm{n}<10$ in either control or osteoporotic women) were excluded from the analysis. Data were considered significant at $p<$ 0.05 . The frequency distributions of VDR genotypes in osteoporotic 
Table 1. Main clinical and biochemical characteristics, BMD, and bone turnover parameters in osteoporotic and control patients

\begin{tabular}{lcr}
\hline & $\begin{array}{l}\text { Osteoporosis } \\
(\mathrm{n}=75)\end{array}$ & \multicolumn{1}{c}{$\begin{array}{c}\text { Control } \\
(\mathrm{n}=66)\end{array}$} \\
\hline Age, years & $53.16 \pm 1.31$ & $52.62 \pm 1.69$ \\
Menopause age, years & $42.09 \pm 0.72$ & $44.42 \pm 0.85$ \\
Weight, $\mathrm{kg}$ & $62.28 \pm 1.06^{* *}$ & $67.56 \pm 1.18$ \\
Height, $\mathrm{m}$ & $1.55 \pm 0.01^{* *}$ & $1.59 \pm 0.01$ \\
Body mass index, $\mathrm{kg} / \mathrm{m}^{2}$ & $25.67 \pm 0.44$ & $26.66 \pm 0.59$ \\
Serum calcium, $\mathrm{mg} / \mathrm{dl}$ & $9.41 \pm 0.17$ & $9.69 \pm 0.06$ \\
Urinary calcium $\mathrm{mg} / \mathrm{day}$ & $131.49 \pm 7.49^{*}$ & $166.32 \pm 13.98$ \\
Osteocalcin, $\mathrm{ng} / \mathrm{ml}$ & $5.03 \pm 0.56^{* * *}$ & $2.61 \pm 0.55$ \\
Hydroxyproline, $\mathrm{mmol} / \mathrm{mol} \mathrm{Cr}$ & $15.87 \pm 1.34$ & $14.75 \pm 1.53$ \\
L1-4 BMD, $/ \mathrm{cm}^{2}$ & $0.80 \pm 0.02^{* * *}$ & $0.93 \pm 0.02$ \\
FN BMD, $/ \mathrm{cm}^{2}$ & $0.68 \pm 0.01^{*}$ & $0.76 \pm 0.02$ \\
Trochanter BMD, $\mathrm{g} / \mathrm{cm}^{2}$ & $0.57 \pm 0.01^{*}$ & $0.66 \pm 0.02$ \\
Ward's BMD, $/ \mathrm{cm}^{2}$ & $0.53 \pm 0.01^{* * *}$ & $0.65 \pm 0.03$ \\
Total BMD, $\mathrm{g} / \mathrm{cm}^{2}$ & $0.76 \pm 0.03^{*}$ & $0.89 \pm 0.09$ \\
\end{tabular}

Values are means $\pm \mathrm{SE}$.

$* \mathrm{p} \leq 0.05 ; * * \mathrm{p} \leq 0.01 ; * * \mathrm{p} \leq 0.001$.

and normal groups were compared using the $\chi^{2}$ test. Both for the osteoporotic and control subjects, BMD levels and bone turnover parameters for the three genotype classes were compared with analysis of variance (ANOVA). Student's t test and the Mann-Whitney test were applied for statistical analysis between the two groups. All data are shown as mean \pm standard error.

\section{Results}

The demographic and major clinical and biochemical values for both osteoporotic and control subjects are given in table 1. The osteoporotic women's height, weight, urinary calcium and all BMD values were significantly lower than those of the control women ( $\mathrm{p} \leq 0.01$ and 0.05 ). Although not significant, the bone resorption marker, hydroxyproline, was higher in the osteoporotic than the control group. Osteoporotic women had significantly higher $(\mathrm{p}<0.001)$ serum osteocalcin levels compared to the control group. After amplification of genomic DNA with VDR-specific primers, followed by digestion with $A p a \mathrm{I}, B s m \mathrm{I}$, or TaqI and agarose gel electrophoresis, restriction fragment length polymorphisms (RFLPs) were determined. No different result was obtained from partial digestion testing. The genotypic frequencies observed for these polymorphisms both in osteoporotic patients and control subjects are shown in table 2 . The genotype fre-
Table 2. Allele and genotype frequencies of the BsmI, ApaI, and TaqI polymorphisms of the VDR gene

\begin{tabular}{|c|c|c|c|c|}
\hline \multirow{2}{*}{$\begin{array}{l}\text { VDR } \\
\text { genotype }\end{array}$} & \multicolumn{2}{|c|}{ Osteoporotic women } & \multicolumn{2}{|c|}{ Control women } \\
\hline & $\begin{array}{l}\text { observed } \\
\mathrm{n}\end{array}$ & $\begin{array}{l}\text { frequency } \\
\%\end{array}$ & $\begin{array}{l}\text { observed } \\
\mathrm{n}\end{array}$ & $\begin{array}{l}\text { frequency } \\
\%\end{array}$ \\
\hline \multicolumn{5}{|l|}{ Bsm I } \\
\hline $\mathrm{Bb}$ & 54 & 72 & 42 & 63.6 \\
\hline $\mathrm{BB}$ & 18 & 24 & 17 & 25.8 \\
\hline $\mathrm{bb}$ & 3 & 4 & 7 & 10.6 \\
\hline \multicolumn{5}{|l|}{ ApaI } \\
\hline Aa & 56 & 74.8 & 45 & 68.2 \\
\hline $\mathrm{AA}$ & 13 & 17.2 & 15 & 22.7 \\
\hline aa & 6 & 8 & 6 & 9.1 \\
\hline \multicolumn{5}{|l|}{$T a q$} \\
\hline $\mathrm{Tt}$ & 42 & 56 & 28 & 42.4 \\
\hline TT & 23 & 30.8 & 23 & 34.9 \\
\hline tt & 10 & 13.2 & 15 & 22.7 \\
\hline
\end{tabular}

Table 3. Frequency of VDR-combined genotypes

\begin{tabular}{lccccc}
\hline $\begin{array}{l}\text { Combined } \\
\text { genotype }\end{array}$ & \multicolumn{2}{l}{$\begin{array}{l}\text { Osteoporotic women } \\
(\mathrm{n}=75)\end{array}$} & & \multicolumn{2}{l}{$\begin{array}{l}\text { Control women } \\
(\mathrm{n}=66)\end{array}$} \\
\cline { 2 - 3 } \cline { 5 - 6 } & $\mathrm{n}$ & $\%$ & & $\mathrm{n}$ & $\%$ \\
\hline BbAaTt & 31 & 41.3 & & 17 & 25.8 \\
BbAatt & 15 & 20 & & 10 & 15.15 \\
bbAaTT & 6 & 8 & & 10 & 15.15 \\
bbaaTt & 5 & 6.76 & & - & - \\
BbaaTt & 3 & 4 & & 5 & 7.57 \\
BBAAtt & 3 & 4 & & 3 & 4.54 \\
Bbaatt & 2 & 2.66 & & 5 & 7.57 \\
bbAaTt & 2 & 2.66 & & 5 & 7.57 \\
\hline
\end{tabular}

quencies in this population were $24 \%$ for $\mathrm{BB}, 72 \%$ for $\mathrm{Bb}$, $4 \%$ for bb, $17.2 \%$ for AA, $74.8 \%$ for Aa, $8 \%$ for aa, $30.8 \%$ for TT, $56 \%$ for Tt, $13.2 \%$ for $\mathrm{tt}$ in the osteoporotic women, and $25.8 \%$ for BB, $63.6 \%$ for $\mathrm{Bb}, 10.6 \%$ for bb, $22.7 \%$ for AA, $68.2 \%$ for Aa, $9.1 \%$ for aa, $34.9 \%$ for TT, $42.4 \%$ for $\mathrm{Tt}$ and $22.7 \%$ for $\mathrm{tt}$ in the control women. The combination of genotypes defined by all three RFLPs is shown in table 3. The BbAaTt, BbAatt, and bbAaTT define the most frequently combined ones $(69.3 \%$ in osteoporotic women, $56.1 \%$ in control women). The most common 
Table 4. Selected characteristics of unrelated osteoporotic and healthy postmenopausal women in relation to VDR gene alleles

\begin{tabular}{|c|c|c|c|c|c|c|c|}
\hline \multirow[t]{2}{*}{ Characteristics } & \multicolumn{2}{|l|}{ Bsm I } & \multicolumn{2}{|l|}{ Apa I } & \multicolumn{3}{|l|}{$\operatorname{Taq} \mathrm{I}$} \\
\hline & $\mathrm{Bb}$ & $\mathrm{BB}$ & $\mathrm{Aa}$ & AA & $\mathrm{Tt}$ & TT & $\mathrm{tt}$ \\
\hline \multicolumn{8}{|l|}{ Osteoporotic women } \\
\hline Number & 54 & 18 & 56 & 13 & 42 & 23 & 10 \\
\hline Age, years & $52.52 \pm 1.62$ & $54.33 \pm 2.48$ & $52.73 \pm 1.54$ & $53.76 \pm 2.99$ & $54.66 \pm 1.84$ & $49.05 \pm 1.87$ & $53.20 \pm 4.24$ \\
\hline Height, m & $1.55 \pm 0.01$ & $1.55 \pm 0.01$ & $1.55 \pm 0.01$ & $1.56 \pm 0.02$ & $1.56 \pm 0.01$ & $1.55 \pm 0.02$ & $1.56 \pm 0.02$ \\
\hline Weight, kg & $61.57 \pm 1.14$ & $65.15 \pm 2.69$ & $62.13 \pm 1.16$ & $62.23 \pm 3.39$ & $63.4 \pm 1.43$ & $60.30 \pm 1.83$ & $60.33 \pm 2.99$ \\
\hline BMI, kg/m² & $25.37 \pm 0.45$ & $27.05 \pm 1.19$ & $25.62 \pm 0.45$ & $25.66 \pm 1.42$ & $26.19 \pm 0.65$ & $24.79 \pm 0.63$ & $24.92 \pm 1.07$ \\
\hline Menopause age, years & $41.81 \pm 0.86$ & $41.77 \pm 1.39$ & $42.27 \pm 0.79$ & $39.69 \pm 1.66$ & $42.61 \pm 0.86$ & $40.51 \pm 1.55$ & $40.70 \pm 1.79$ \\
\hline Serum Ca, mg/dl & $9.40 \pm 0.21$ & $9.49 \pm 0.33$ & $9.49 \pm 0.16$ & $9.06 \pm 0.67$ & $9.51 \pm 0.22$ & $9.29 \pm 0.29$ & $9.22 \pm 0.58$ \\
\hline Urinary $\mathrm{Ca}, \mathrm{mg} /$ day & $136.99 \pm 8.94$ & $114.12 \pm 15.59^{*}$ & $127.33 \pm 8.63$ & $114.09 \pm 16.88$ & $128.29 \pm 8.37$ & $127.51 \pm 14.67$ & $143.72 \pm 28.42$ \\
\hline \multicolumn{8}{|l|}{ Control women } \\
\hline Number & 42 & 17 & 45 & 15 & 28 & 23 & 15 \\
\hline Age, years & $50.11 \pm 1.59$ & $50.14 \pm 2.59$ & $50.22 \pm 1.67$ & $53.66 \pm 5.20$ & $50.30 \pm 2.57$ & $56.11 \pm 3.09$ & $67.9 \pm 2.26$ \\
\hline Height, m & $1.60 \pm 0.01$ & $1.58 \pm 0.02$ & $1.59 \pm 0.01$ & $1.61 \pm 0.01$ & $1.60 \pm 0.01$ & $1.62 \pm 0.01$ & $1.58 \pm 0.02$ \\
\hline Weight, kg & $66.38 \pm 1.30$ & $68.57 \pm 2.64$ & $66.53 \pm 1.55$ & $68.92 \pm 0.92$ & $66.51 \pm 2.09$ & $68.61 \pm 1.25$ & $65.41 \pm 3.1$ \\
\hline BMI, $\mathrm{kg} / \mathrm{m}^{2}$ & $25.92 \pm 0.68$ & $27.43 \pm 1.10$ & $26.37 \pm 0.78$ & $26.70 \pm 0.36$ & $26.12 \pm 1.08$ & $26.97 \pm 0.74$ & $26.50 \pm 1.33$ \\
\hline Menopause age, years & $44.00 \pm 1.06$ & $44.85 \pm 1.87$ & $43.89 \pm 0.99$ & $45.0 \pm 2.07$ & $43.55 \pm 1.48$ & $46.33 \pm 1.05$ & $47.70 \pm 1.81$ \\
\hline Serum Ca, mg/dl & $9.80 \pm 0.08$ & $9.54 \pm 0.05^{*}$ & $9.63 \pm 0.06$ & $9.85 \pm 0.14$ & $9.67 \pm 0.08$ & $9.81 \pm 0.14$ & $9.55 \pm 0.04$ \\
\hline Urinary $\mathrm{Ca}, \mathrm{mg} /$ day & $178.9 \pm 20.2$ & $151.00 \pm 8.39$ & $159.03 \pm 6.83$ & $189.15 \pm 60.08$ & $186.15 \pm 31.2$ & $146.2 \pm 11.90$ & $149.70 \pm 7.91$ \\
\hline
\end{tabular}

Values are means $\pm \mathrm{SE}$.

$* \mathrm{p}<0.05$. Student's t test was used to compare the characteristics between the alleles of the VDR genes (BsmI, ApaI), whereas ANOVA was used to test for the difference across the TaqI genotypes. BMI = Body mass index.

genotype combination in postmenopausal osteoporotic and control women was BbAaTt.

The relationship between VDR gene alleles and selected characteristics of osteoporotic and control subjects is shown in table 4. In osteoporotic and control women, there were no significant differences in age, age at menopause, height, weight or body mass index among the common genotypes in Bsm I, ApaI, and TaqI RFLPs. Urinary calcium concentration was to be found lower in the osteoporotic women with the BB genotype than in those carrying $\mathrm{Bb}(\mathrm{p}<0.05)$. Table 5 demonstrates BMD and bone turnover markers with respect to VDR gene alleles in osteoporotic and control subjects. Hydroxyproline levels were significantly lower in $\mathrm{BB}$ than in the Bb genotype in osteoporotic women $(p<0.05)$; in contrast to osteoporotic women, hydroxyproline levels in the control group were significantly different with respect to genotype, in which lower values were found in Bb than BB. Although serum osteocalcin levels were not significantly different according to BsmI and ApaI genotypes, higher concentrations were observed in the $\mathrm{BB}$ and $\mathrm{AA}$ for osteoporotic women. For the control women, osteocalcin levels were found to differ according to the ApaI genotype, where AA carriers had higher levels compared to Aa $(\mathrm{p}<0.01)$, but no such difference was observed between BsmI genotypes. In osteoporotic women serum osteocalcin levels were found to be highest in the $\mathrm{tt}$ genotype and lowest in the $\mathrm{Tt}$, and intermediate in the TT genotype $(\mathrm{p}<0.05)$.

There is some evidence of a relationship with higher BMD levels associated with the $T$ allele at the FN. Our data showed significant TaqI-related differences in the osteoporotic women in FN as well as L1-4, trochanter and Ward's BMD. The osteoporotic group with the TT genotype had significantly higher FN $(p<0.05)$, trochanter $(\mathrm{p}<0.01), \mathrm{L} 1-4(\mathrm{p}<0.05)$ and Ward's $(\mathrm{p}<0.05)$ BMD values with respect to the th genotype.

\section{Discussion}

In the last two decades, compelling data have been obtained indicating that BMD is, at least in part, genetically determined $[15,16,18,19]$. In the present study, we analyzed ApaI, BsmI, and TaqI VDR polymorphisms and addressed the question whether BMD was affected by the VDR gene polymorphisms in postmenopausal osteoporotic women as well as healthy control subjects. The observed VDR genotype distributions were similar to pre- 
Table 5. BMD and bone turnover markers according to different VDR gene alleles in unrelated osteoporotic and healthy postmenopausal women

\begin{tabular}{|c|c|c|c|c|c|c|c|}
\hline \multirow[t]{2}{*}{ Characteristics } & \multicolumn{2}{|l|}{ Bsm I } & \multicolumn{2}{|l|}{$A p a \mathrm{I}$} & \multicolumn{3}{|l|}{ TaqI } \\
\hline & $\mathrm{Bb}$ & BB & Aa & AA & $\mathrm{Tt}$ & TT & $\mathrm{tt}$ \\
\hline \multicolumn{8}{|l|}{ Osteoporotic women } \\
\hline Number & 54 & 18 & 56 & 13 & 42 & 23 & 10 \\
\hline Osteocalcin, ng/ml & $4.92 \pm 0.58$ & $5.45 \pm 1.54$ & $4.92 \pm 0.59$ & $5.93 \pm 1.26$ & $4.27 \pm 0.57$ & $5.24 \pm 0.79$ & $8.69 \pm 2.94^{*}$ \\
\hline Hydroxyproline, $\mathrm{mmol} / \mathrm{mol} \mathrm{Cr}$ & $16.42 \pm 1.60$ & $14.47 \pm 2.92 *$ & $17.03 \pm 1.63$ & $13.33 \pm 2.94$ & $16.16 \pm 1.84$ & $14.96 \pm 1.79$ & $20.00 \pm 5.17$ \\
\hline $\mathrm{L} 1-4 \mathrm{BMD}, \mathrm{g} / \mathrm{cm}^{2}$ & $0.79 \pm 0.02$ & $0.84 \pm 0.04$ & $0.79 \pm 0.02$ & $0.83 \pm 0.05$ & $0.77 \pm 0.02$ & $0.87 \pm 0.03^{*}$ & $0.80 \pm 0.05$ \\
\hline FN BMD, $\mathrm{g} / \mathrm{cm}^{2}$ & $0.69 \pm 0.01$ & $0.67 \pm 0.02$ & $0.69 \pm 0.01$ & $0.69 \pm 0.02$ & $0.68 \pm 0.02$ & $0.73 \pm 0.02 *$ & $0.63 \pm 0.03$ \\
\hline Trochanter BMD, $\mathrm{g} / \mathrm{cm}^{2}$ & $0.58 \pm 0.01$ & $0.56 \pm 0.02$ & $0.57 \pm 0.01$ & $0.57 \pm 0.02$ & $0.56 \pm 0.01$ & $0.63 \pm 0.02 * *$ & $0.52 \pm 0.02$ \\
\hline Ward's BMD, g/cm² & $0.54 \pm 0.02$ & $0.51 \pm 0.03$ & $0.54 \pm 0.02$ & $0.54 \pm 0.03$ & $0.52 \pm 0.02$ & $0.61 \pm 0.02 *$ & $0.47 \pm 0.04$ \\
\hline \multicolumn{8}{|l|}{ Control women } \\
\hline Number & 42 & 17 & 45 & 15 & 28 & 23 & 15 \\
\hline Osteocalcin, ng/ml & $2.55 \pm 0.73$ & $2.77 \pm 1.04$ & $1.86 \pm 0.44$ & $5.50 \pm 1.55^{* *}$ & $2.75 \pm 0.92$ & $2.31 \pm 0.89$ & $2.82 \pm 1.24$ \\
\hline Hydroxyproline, $\mathrm{mmol} / \mathrm{mol} \mathrm{Cr}$ & $13.27 \pm 0.84$ & $20.98 \pm 4.41 *$ & $15.79 \pm 2.00$ & $11.64 \pm 2.46$ & $16.17 \pm 2.65$ & $12.68 \pm 2.03$ & $15.30 \pm 3.64$ \\
\hline $\mathrm{L} 1-4 \mathrm{BMD}, \mathrm{g} / \mathrm{cm}^{2}$ & $0.93 \pm 0.03$ & $0.95 \pm 0.01$ & $0.96 \pm 0.03$ & $0.89 \pm 0.03$ & $0.95 \pm 0.03$ & $0.88 \pm 0.05$ & $0.90 \pm 0.02$ \\
\hline FN BMD, $\mathrm{g} / \mathrm{cm}^{2}$ & $0.79 \pm 0.03$ & $0.71 \pm 0.03$ & $0.80 \pm 0.03$ & $0.67 \pm 0.01^{*}$ & $0.78 \pm 0.04$ & $0.74 \pm 0.04$ & $0.76 \pm 0.04$ \\
\hline Trochanter BMD, $\mathrm{g} / \mathrm{cm}^{2}$ & $0.69 \pm 0.03$ & $0.63 \pm 0.03$ & $0.69 \pm 0.03$ & $0.60 \pm 0.02$ & $0.65 \pm 0.03$ & $0.67 \pm 0.04$ & $0.68 \pm 0.04$ \\
\hline Ward's BMD, $\mathrm{g} / \mathrm{cm}^{2}$ & $0.68 \pm 0.04$ & $0.60 \pm 0.04$ & $0.69 \pm 0.04$ & $0.57 \pm 0.02$ & $0.65 \pm 0.05$ & $0.64 \pm 0.06$ & $0.68 \pm 0.06$ \\
\hline
\end{tabular}

Values are means $\pm \mathrm{SE}$.

${ }^{*} \mathrm{p}<0.05 ;{ }^{* *} \mathrm{p}<0.01$. Student's $\mathrm{t}$ test was used to compare the characteristics between the alleles of the VDR genes (BsmI, ApaI), whereas ANOVA was used to test for the difference across the TaqI genotypes.

vious reports $[16,17]$. It is expected that BMD is determined by genetic and environmental interacting influences. FN BMD was found to be decreasing continually with growing age, in both women and men even in the late decades of life [29]. The differential effects of VDR alleles on BMD among different populations could partly explain the differences between Italian and Irish studies $[30,31]$.

We found significant effects of VDR gene alleles on bone mass. TaqI genotypes were found to have a striking effect on all BMD values studied. The TT genotype-carrying osteoporotic women had higher BMD levels compared to either $\mathrm{Tt}$ or $\mathrm{tt}$. The same effect of TaqI polymorphisms on BMD could not be observed in healthy women. Our observation is in good agreement with the finding of Spector et al. [15] who confirmed the link between the VDR genotype (TaqI poymorphism) and BMD in postmenopausal British twins. In their study, postmenopausal twins with the TT genotype had an about 10\% higher bone density than women with the tt genotype.

Various studies have shown that obesity can mask the influence of the VDR genotypes. Dawson-Hughes et al. [32] showed that women with the BB genotype of the VDR gene had a reduced efficiency in calcium absorption and a low calcium intake compared to women of the bb genotype consistent with a functional defect in the intestinal VDR. The impact of this heritable difference is reduced at higher calcium intakes. This evidence is consistent with the fact that the relationship between the VDR genotypes and FN bone loss rate is enhanced at low calcium intakes in postmenopausal women. In obese postmenopausal women, estrogen concentrations appear to increase [33]. This estrogen increase in obese women may mask the relationship of VDR polymorphisms with BMD. For these reasons overtly obese women were not included in our study. Vandevyver et al. [34] concluded that the VDR gene polymorphism influences FN and BMD in nonobese postmenopausal women. They found that the link between VDR genotypes and FN and BMD is not seen in obese postmenopausal women, which suggests that factors related to obesity obscure such an effect in overweight women.

Although no significant differences were observed between the genotypic distribution of the VDR gene in the osteoporotic and control groups in our study, for each of the three loci tested, heterozygous classes had a higher frequency in osteoporotics than in controls, which implies a heterozygous disadvantage. Furthermore, the BMD val- 
ues for the different sites were not found to associate with any of the BsmI and ApaI genotypes in osteoporotic women, which means that no relationship between the VDR BsmI polymorphism and osteoporosis was observed. We found a close relation between TaqI genotypes and BMD values at all sites studied in the osteoporotic women. The L1-4, FN, trochanter and Ward's BMD levels differed with respect to $T a q$ I polymorphism and all were significantly higher in the osteoporotic women with TT genotype compared to $\mathrm{Tt}$ and $\mathrm{tt}$, which demonstrates the relationship between VDR TaqI polymorphism and osteoporosis. Sheehan et al. [31] reported 29 and 40\% higher osteocalcin levels of the $\mathrm{tt}$ genotype compared to the $\mathrm{Tt}$ and TT genotypes, respectively, in healthy adults. According to our results the tt VDR genotype was associated with significantly higher serum osteocalcin compared with the $\mathrm{Tt}$ and TT genotypes, 50.8 and 39\%, respectively, in the osteoporotic women, whereas no such association was found in the healthy women. The effects we observed in our subjects are of genetic and biological significance.

\section{Conclusion}

This study shows an association between the VDR gene TaqI polymorphism and BMD at the FN, lumbar spine, trochanter and Ward's triangle in a group of nonobese, postmenopausal osteoporotic women. Thus, the VDR gene TaqI polymorphism modulates differences in BMD in the postmenopausal osteoporotic women, although the interaction of the gene and BMD and the role of VDR genotypes deserve further study with larger numbers of subjects.

\section{Acknowledgments}

This work was supported by the Research Fund of the University of Istanbul, project numbers 1024/250897 and B-1298/03102001.

\section{References}

1 Pocock NA, Eisman JA, Hopper JL, Yeates MG, Sambrook PN, Eberl S: Genetic determinants of bone mass in adults. J Clin Invest 1987;80:706-710.

2 Christian JC, Yu PL, Slemenda CW, Johnston CC: Heritability of bone mass: A longitudinal study in aging male twins. Am J Hum Genet 1989;44:429-433

3 Smith DM, Nance WE, Kang KW, Christian JC, Johnston CC Jr: Genetic factors in determining bone mass. J Clin Invest 1973;52: 2800-2808.

4 Dequeker J, Nijs J, Verstraeten A, Geusens P, Gevers G: Genetic determinants of bone mineral content at the spine and radius: A twin study. Bone 1987;8:207-209.

5 Kelly PJ, Hopper JL, Macaskill GT, Pocock NA, Sambrook PN, Eisman JA: Genetic factors in bone turnover. J Clin Endocrinol Metab 1991;72:808-813.

6 Lutz J: Bone mineral, serum calcium and dietary intakes of mother/daughter pairs. Am J Clin Nutr 1986;44:99-106.

7 Seeman E, Hopper JL, Bach LA, Cooper ME Parkinson E, McKay J, Jerums G: Reduced bone mass in daughters of women with osteoporosis. N Engl J Med 1989;320:554-558.

8 Morrison NA, Yeoman R, Kelly PJ, Eisman JA: Contribution of trans-acting factor alleles to normal physiological variability: Vitamin D receptor gene polymorphism and circulating osteocalcin. Proc Natl Acad Sci USA 1992;89: 6665-6669.

Polymorphisms in the Vitamin D Receptor

Gene and Bone Mass
9 Morrison NA, Qi JC, Tokita A, Kelly PJ, Crofts L, Nguyen TV, Sambrook PN, Eisman JA: Prediction of bone density from vitamin D receptor alleles. Nature 1994;367:284-287.

10 Eisman JA, Morrison NA, Kelly PJ, Sambrook PN, Howard G, Qi J, Tokita A, Crofts L, Nguyen TV, Birmingham J: Genetics of osteoporosis and vitamin $\mathrm{D}$ receptor alleles. Calcif Tissue Int 1995;56:S48-49.

11 Peacock M: Vitamin D receptor gene alleles and osteoporosis: A contrasting view. J Bone Miner Res 1995;10:1294-1297.

12 Yamagata Z, Miyamura T, Iijima S, Asaka A, Sasaki M, Kato J, Koizumi K: Vitamin D receptor gene polymorphism and bone mineral density in healthy Japanese women. Lancet 1994;344:1027.

13 Krall EA, Parry P, Lichter JB, Dawson-Hughes B: Vitamin D receptor alleles and rates of bone loss: Influences of years since menopause and calcium intake. J Bone Miner Res 1995;10: 978-984.

14 Ferrari S, Rizzoli R, Chevalley T, Slosman D, Eisman JA, Bonjour J-P: Vitamin D receptor gene polymorphisms and chance in lumbar spine bone mineral density. Lancet 1995;345: 423-424.

15 Spector TD, Keen RW, Arden NK, Morrison NA, Major PJ, Nguyen TV, Kelly PJ, Baker JR, Sambrook PN, Lanchbury JS, Eisman JA: Influence of vitamin D receptor genotype on bone mineral density in postmenopausal women: A twin study in Britain. BMJ 1995;310: 1357-1360.
16 Fleet JC, Harris SS, Wood RJ, Dawson-Hughes B: The BsmI vitamin D receptor restriction fragment length polymorphism (BB) predicts low bone density in premenopausal black and white women. J Bone Miner Res 1995;10:985990.

17 Riggs BL, Nguyen TV, Melton LJ 3rd, Morrison NA, O'Fallon WM, Kelly PJ, Egan KS, Sambrook PN, Muhs JM, Eisman JA: The contribution of vitamin $\mathrm{D}$ receptor gene alleles to the determination of bone mineral density in normal osteoporotic women. J Bone Miner Res 1995;10:991-996.

18 Garnero P, Borel O, Sornay-Rendu E, Delmas PD: Vitamin D receptor gene polymorphisms do not predict bone turnover and bone mass in healthy premenopausal women. J Bone Miner Res 1995;10:1283-1288.

19 Keen RW, Major PJ, Lanchbury JS, Spector TD: Vitamin D receptor gene polymorphism and bone loss. Lancet 1995;345:990.

20 Looney J, Yoon HK, Fischer SM, Farley SM, Farley JR, Wegedal JE, Baylink DJ: Lack of a high prevalence of the $\mathrm{BB}$ vitamin $\mathrm{D}$ receptor genotype in severely osteoporotic women. J Clin Endocrinol Metab 1995;80:2158-2162.

21 Kroger H, Mahonen A, Ryhanen S, Turunen AM, Alhava E, Maenpaa P: Vitamin D receptor genotypes and bone mineral density. Lancet 1995;345:1238.

22 Lim SK, Park YS, Park JM, Song YD, Lee EJ, Kim KR, Lee HC, Huh KB: Lack of association between vitamin $\mathrm{D}$ receptor genotypes and osteoporosis in Koreans. J Clin Endocrinol Metab 1995;80:3677-3681. 
23 Hustmyer FG, Peacock M, Hui S, Johnston $\mathrm{CC}$, Christian J: Bone mineral density in relation to polymorphism at the vitamin D receptor gene locus. J Clin Invest 1994;94:2130 2134.

24 Parfitt A: Vitamin D receptor genotypes in osteoporosis. Lancet 1994;344:1580.

25 Shiraki M, Eguchi H, Aoki C, Shiraki Y: Can allelic variations in vitamin $\mathrm{D}$ receptor gene predict bone densities and serum osteocalcin level in Japanese women. Bone 1995;16(suppl 1):84S.

26 Ho KC, Pang C: Automated analysis of urinary hydroxyproline. Clin Chim Acta 1989;185: 191-196.

27 Miller SA, Dykes DD, Polesky HF: A simple salting out procedure for extracting DNA from nucleated cells. Nucleic Acids Res 1998;16: 1215.
28 Saiki RK, Gelfand DH, Stoffel S, Scharf SJ, Higuchi R, Horn GT, Mullis KB, Erlich HA: Primer directed enzymatic amplification of DNA with a thermostable DNA polymerase. Science 1988;239:487-491.

29 Jones G, Nguyen TV, Sambrook PN, Kelly PJ, Eisman JA: Progressive loss of bone in the femoral neck in elderly people: Longitudinal findings from the Dubbo osteoporosis epidemiology study. Br Med J 1994;309:691-695.

30 Poggi M, Aterini S, Nicastro L, Chiarugi V, Ruggiero M, Pacini S, Gulisaro M: Lack of association between body weight, bone mineral density and vitamin D receptor gene polymorphism in normal and osteoporotic women. Dis Markers 1999;15:221-227.
31 Sheehan D, Bennett T, Cashman KD: An assessment of genetic markers as predictors of bone turnover in healthy adults. J Endocrinol Invest 2001;24:236-245.

32 Dawson-Hughes B, Harris SS, Finneran S: Calcium absorption on high and low calcium intakes in relation to vitamin D receptor genotypes. J Clin Endocrinol Metab 1995;80:36573661.

33 Kirschner MA, Samojlik E, Drejka M, Szmal E, Schneider G, Ertel N: Androgen-estrogen metabolism in women with upper body versus lower body obesity. J Clin Endocrinol Metab 1990;70:473-479.

34 Vandevyver C, Wylin T, Cassiman J, Raus J, Geusens P: Influence of the vitamin D receptor gene alleles on bone mineral density in postmenopausal and osteoporotic women. J Bone Miner Res 1997;12:241-247. 